\title{
COVID-19 AND CREMATION OF HUMAN CORPSE DURING DISASTER: NATIONAL SECURITY VS RELIGION BELIEF
}

\author{
LOH ING HOE*1, CHONG JU LIAN ${ }^{2}$, MOHD KHAIRUL AMRI KAMARUDIN ${ }^{3,4}$ AND \\ ROSLAN UMAR ${ }^{5}$
}

${ }^{1}$ School of Business and Management, Royal Melbourne Institute of Technology University, Vietnam, Handi Resco Building, 521 Kim Ma, Ba Dinh District, Hanoi, Vietnam. ${ }^{2}$ Faculty of Science and Marine Environment \& Institute of Tropical and Biodiversity and Sustainable Development, Universiti Malaysia Terengganu, 21030 Kuala Nerus, Terengganu, Malaysia.

${ }^{3,4}$ Faculty of Applied and Social Sciences @ East Coast Environmental Research Institute (ESERI), Universiti Sultan Zainal Abidin, Gong Badak Campus, 21300 Kuala Nerus, Malaysia. ${ }^{5}$ East Coast Environmental Research Institute (ESERI), Universiti Sultan Zainal Abidin, Gong Badak Campus, 21300 Kuala Nerus, Malaysia.

*Corresponding author:loh.inghoe@rmit.edu.vn

Submitted final draft: 4 September $2020 \quad$ Accepted: 23 September $2020 \quad$ http://doi.org/10.46754/jssm.2021.01.005

\begin{abstract}
Coronavirus (COVID-19) has become a pandemic worldwide. The number of deaths is increasing without a vaccine to stop its spread and has threatened Malaysia's national security. With the increased number of human fatalities due to COVID-19, cremation may be the final solution to prevent the spread from dead bodies as the virus remains on the body after death. However, religion has different perspectives in dealing with the cremation of the dead body. Malaysia is a Muslim majority country but its citizens also consisted of Christians, Hindus, Buddhists, and others. This study will look at the acceptance of Malaysians on the issue of cremating dead bodies during disasters. A qualitative approach was used with respondents answering questionnaires. Analysis of legislation related to disaster management of human corpses was also conducted. Results show that the majority of the respondents disagreed with the cremation of the dead body because of their religion and they believe that there must be a better alternative to deal with the dead body infected by COVID-19.
\end{abstract}

Keywords: COVID-19, Malaysia, dead body, legislation, religious.

\section{Introduction}

The world is currently facing major impacts from the coronavirus disease 2019 (COVID-19). Many cities have been locked down as the numbers of infected COVID-19 people as well as the death toll due to the complications caused by COVID-19 steadily climb. It is undeniable that COVID-19 has a huge impact on the economy and the health care system of most countries affected. Italy, Spain, and the United States of America as a few of the countries facing the worst situation are struggling to protect their citizens from COVID-19. As death rates keep on increasing, a clear guideline and legislation on the cremation of human corpses during disasters is needed to ensure the safety and security of society. Cremation could be the best option as it deals with the disposal of dead bodies speedily, saves land space, and alsodeals with valid concerns of dead bodies being close to the soil surface and drinking water sources. Moreover, with the nature of COVID-19 and its ease to infect others, cremation of human corpses may be the best solution for disposing of the fatalities due to the disease. This is since the virus has been recorded to remain on the surface of the skin of its victims (The Malay Mail, 2020).

However, not all religions approved the cremation of human corpses (Loh \& Chong, 2019). Some religions recognised the cremation of human corpses while others forbade the dead body to be cremated. For instance, in Judaism, a strict era Modern Orthodox, Orthodox, Haredi, and Hasidic movements have maintained a strict biblical line against cremation and disapprove of it as Halakha (Jewish law) forbids it. Torah in Devarim (Deuteronomy) 21:23 states that "Bury, you will bury him the same day; for the (unburied body) is a curse to God" with this 

perceived as both a positive command derived from this verse to command one to bury a dead body and a negative command forbidding the neglect to bury a dead body (Wikipedia, 2020).

On the other hand, Sikhism believes in reincarnation, with the soul passing through different births until it achieves mukti, or liberation. If possible, a dead body should be cremated within a day. The body is placed in the coffin and taken to the gurdwara where it is placed in front of the Guru Granth Sahib. The coffin is then taken to the place of cremation. The cremation ceremony is known as the 'atam sanskar', or ceremony of completion (Uzell, 2018). Further details on particulars regarding the cremation of the dead body in Malaysia based on religious beliefs will be discussed as follows.

In 1992 the United Nations recognized that for an event to be classified as a disaster it must overwhelm the response capability of a community. An international disaster is defined as a serious disruption of the functioning of society, causing widespread human, material, or environmental losses that exceed the ability of the affected society to cope using only its resources (Jha, 2010). As such, disasters can be more accurately summarized as the collective stress situations occurring at a community level as a result of major unwanted consequences (Hutton, 2001). According to Kume (2006), regardless of the terminology used and the type of event either natural or human, generally there is consensus that a disaster is an event that involves the destruction of property, injury, and/ or loss of life; has an identifiable beginning and end; adversely affects a relatively large group of people; is 'public' and shared by members of more than one family; is out of the realm of ordinary experience; and psychologically, is traumatic enough to induce distress in almost anyone.

In the case of death during disasters, it is reasonably foreseeable that the next of kin may commence legal action against the government for disposing of their loved one's remains without prior consent from the family members. Additionally, no legislation in Malaysia allows the government to cremate human corpses during disasters to prevent any further infection to others (Loh et al., 2017). However, it should be noted that the practice of cremation is prohibited under international law except for hygiene and sanitary reasons. The Haiti earthquake in 2010 and its solution to massive numbers of human corpses by burying them in massive graves without identifying the deceased had shown up the lack of legislation which serves as a guideline to proper disposal of the human corpses with respect (Loh \& Chong, 2019). Without national legislation to allow government agencies to cremate human corpses during disasters such as the situation we are facing now with COVID-19, the possibility for the government to be sued is predictable.

The existing Malaysia legislation about disaster management, namely the National Security Council, Directive No 20 Policy and Mechanism of National Disaster Relief and Management only focuses on the coordination and regulation of government agencies when dealing with disaster. The only act which applies to human corpses is the Infectious Disease Act 1988 (Loh \& Chong, 2019). Under section

17 of the Infectious Act, no human corpse shall be disposed of without authorization from an authorized officer. The seriousness of COVID19 and its effect on Malaysia is yet to be known but the number of fatalities has increased tremendously. Even though Malaysia has declared a lockdown across the country, however, the infection is still spreading.

During a disaster, national security is of the utmost importance. According to Kaczmarek et al. (2002), national security means the ability of a nation to protect its internal values "from external threats". Kitler (2011) reported that national security is the most important value, the national need and priority goal of state activity, individuals and social groups, while it is also a process involving a range of measures to guarantee stable, interference-free existence and national development (state), including protecting individuals and society, their property and natural environment from the risks that 
significantly limit its functioning or threaten the goods that are under special protection. Zie and Zajac (2010) defined national security as the ability of the state and its people (society) to assure survival (the state as an institution, the nation as an ethnic group, the biological survival of the population), territorial integrity, political independence, internal stability and quality of life. This confidence is shaped by actions involving the elimination of negative external threats in the state and affirmative actions to ensure the survival, possession (identity), functioning, and the freedom of development of the state and the nation (society).

On the other hand, religion has much influence on social policy. About $84 \%$ of the world's population is affiliated with one of the five largest religions namely Christianity, Islam, Hinduism, Buddism, or folk religion (Hackett et al., 2015). Religion plays a major role in influencing people's attitudes towards the cremation of their loved one. According to Rebay-Salisbury (2012), choosing whether to inhume or cremate a body after death is a situation people are rarely confronted with; burial practices are normally tied with longstanding traditions and non-discursive practices, whose original meanings might not be even apparent to the participants of the burial rituals themselves. Things are done in a particular way because they are reminded that it has always been done so, and this in turn is what makes these the right things to do. Childe (1944), Piggott (1965), and Clark (1960) in their crosscultural study of 31 non-state societies using the Human Relations Area Files found that mortuary practices take philosophical-religious factors into account. The study revealed several very interesting associations between burial practices and beliefs. It was found that beliefs were documented to determine variation in mortuary practices more often than any other factors in all types of societies (Rebay- Salisbury, 2012). The treatment of a dead body, the building of a grave structure, and the performance of funerary rituals are actions that build on beliefs about the body as well as embodied knowledge (RebaySalisbury, 2012).
Some religions such as Islam forbid the cremation of the dead body. However, in a state of disaster, will society put aside their religion and belief to allow national security to take precedent? This study gathered public opinion on the cremation of human corpses during the state of disaster with reasons behind their viewpoints to better understand their behavior towards cremation practice during the state of disaster.

\section{Materials and Methods}

Qualitative questionnaires and content analysis studies were utilised in this study. The questionnaires, as well as the instructions the respondents received, were designed based on the idea that questions should be answered neutrally and objectively (Eckerdal \& Hagstrom, 2017). Several authors speak of the questionnaires' governing nature on why a particular question is asked at all and how the phrasing of a question shapes the answers, but a question can also get surprising answers that can open unexpected perspectives (Eckerdal \& Hagstrom, 2017). This study looked at the public perception of the cremation of human corpses during a disaster. As such, we targeted members of the public with different religions as respondents in this study. Although there were previous studies conducted in the area of disaster management, little or none was of human corpse cremation during the state of disaster. As such, the main objective of this study is to investigate the different perceptions in respect of the implementation of cremation in Malaysia during a state of disaster.

To obtain these validations, the design of the instrument has to (1) obtain opinions, perceptions, and viewpoints of the public on cremation and (2) the reasons influencing their viewpoints. For the respondents to have clarity of thought and have a full understanding of the questions, the meaning of cremation has been explained to the respondents in the introduction of the questionnaire. The questionnaire was posted in Google Form and the respondents were invited to answer the questionnaire. The questionnaire template is divided into 2 sections, 
and the sections are namely (1) demographic information, and (2) whether they agree with the implementation of cremation in Malaysia during the state of disaster and their reasons. Demographic data for the public collected are as follows: gender, age, race, and religion.

To ensure the reliability of the data collected, the QSR Nvivo software was chosen to analyse data obtained in this qualitative study. Besides, qualitative document analysis also was adopted in this study to identify relevant treaties and legislations related to cremation of human corpses, as documents provide evidence of policy directions, legislative intent, understandings of perceived shortcoming or best practice in the legal system, and agenda for change (Bloch, 1992).

\section{Results and Discussion}

\section{Legislation related to Cremation of Human Corpse in the State of Disaster}

From the international law perspective, Article 20 of the Convention (II) for the Amelioration of the Condition of Wounded, Sick and Shipwrecked Members of Armed Force at Sea (Convention II) and Article 120 of the Convention (IV) relative to the Protection of Civilian Persons in Time of War (Convention IV) state that all parties in armed conflict should take measures to identify the dead before burying them or burning them. Parties to the conflicts shall ensure that burial or cremation of the dead, carried out individually as far as circumstances permit, is preceded by careful examination, if possible by a medical examination of the bodies, to confirm the death, establishing the identity of the deceased to enable a report to be made. Additionally, Article 17 of the Convention (I) for the Amelioration of the Condition of the Wounded and Sick in Armed Forces in the Field (Convention I), and Article 120 of the Convention (III) relative to the Treatment of Prisoner of War (Convention III) state that bodies shall not be cremated except for imperative reasons of hygiene or motives based on the religion of the deceased. In the case of cremation, the circumstances and reasons for cremation shall be stated in detail in the death certificate or on the authenticated list of the dead. Article 19 of the Convention II and Article I of the Protocol (I) Additional to the Geneva Convention and relative to the protection of Victims of International Armed Conflicts (Protocol I) state that all parties have to do all that is possible to provide information on the identity, the location, and the cause of death of the deceased to the responsible authorities or the deceased's next of kin or relatives.

Under customary international humanitarian law, Article 115 emphasizes that the dead must be buried, if possible, according to the rites of the religion to which they belonged and that they may only be cremated under exceptional circumstances, such as imperative reasons of hygiene, on account of the religion of the deceased or following the expressed wish of the deceased. Article 116 requires each party to record all available information for identification purposes before the procedure of disposal and to mark the location of the graves. The only difference when adopting the said articles in disaster management of human corpses such as the situation with COVID-19 is that cremation will be the common practice for infected COVID-19 deceased instead of considering the deceased's religious practice and belief.

Meanwhile, in Malaysia, Section 17 of the Infectious Disease Act states that where a person has died of infectious disease and an authorized officer has given direction as to how the corpse of such person is to be buried or cremated, no person shall bury or cremate such corpse otherwise than following the directions of the authorized officer. Section 17 of the Infectious Disease Act is applicable in disaster management of human corpses where no human corpse shall be disposed of without authorization from an authorized officer. The other relevant Malaysia legislation mostly deals with the management of disaster areas, transportation, safety, government agencies, and general procedure. The only specific law governing disaster management, in general, is the National Security Council, Directive 20 on the Policy and Mechanism on National Disaster 
and Relief Management. However, cremation is an issue that has not been mentioned in the Directive (Loh \& Chong, 2019).

\section{Religion and Cremation in Malaysia}

This research only focuses on major religious practices in Malaysia. While cremation is not preferred among most Christians, it is not entirely a forbidden practice. Some of the more conservative denominations assert there is specific content in the Bible that discourages the practice of cremation. For instance, in the Old Testament, Deuteronomy 34:6 implies that God chose burial for Moses after he died. Corinthians 15:35-55 states "Then, when our dying bodies have been transformed into bodies that will never die, this Scripture will be fulfilled. While Thessalonians 4: 16 states "For the Lord himself will come down from heaven, with a loud command, with the voice of the archangel and with the trumpet call of God, and the dead in Christ will rise first."

For those of the Muslim faith, cremation is forbidden. Burning the dead is considered aform of mutilation, forbidden by Allah s.w.t. As such, Islam instructs its followers to bury their dead as quickly as possible, preferably within the day of the death. To justify the claim of non- cremation, they refer to two Qur'anic verses. First, 5:53 states "So God sent a crow scratching in the ground to show him how to bury his brother's corpse. The claim is that God elated this story to us to teach us the correct method of disposing of a dead body (Muhammad, 2001). Thus, any other method of disposing of a dead body is prohibited by God. Second, 17:70 states that "We have honored the children of Adam and carried them on the land and in the sea and We provided them with good things, and We favored them considerably over many of those We created." The claim is that in keeping with the spirit of this verse, it is necessary to treat the human body with the utmost respect, not only when a person is alive, but also when he/she is dead. Cremating the deceased or discarding bodies in other ways is considered sacrilege and abhorrent and, therefore, forbidden according to Islam (Muhammad, 2001).

Buddhism is one of the few religions in which cremation is viewed as an acceptable practice. Many Buddhists prefer cremation over burial to follow in the footsteps of Siddhartha Gautama, the Buddha who was himself cremated. If the body is to be cremated, monks may be present at the cremation and to lead the chanting for the dead. If no monks are present, family members may lead to chanting (Everplan, 2020). For Hinduism, cremation is mandatory, called 'antim sanskar' or the last rite. In cremation, Hindus believe that the body is presented as an offering to Agni, the Hindu God of Fire, accompanied by a prayer to purify the deceased and lead them to a better life. Cremating the body also helps detach the subtle body, that of the mind and vital energies from the gross body which is physical and mortal, and enables the subtle body to pass on, instead of lingering around loved ones who are still alive (Cremation, 2020).

\section{Finding from the Questionnaire survey}

From the questionnaire survey, results have been added into tables as below.

Table 1: Total number of respondents

\begin{tabular}{lcc}
\hline \multicolumn{1}{c}{ Religion } & Number of respondents & Percentage (\%) \\
\hline Muslim & 76 & 69 \\
Christian & 11 & 10 \\
Buddhism & 14 & 13 \\
Hindu & 9 & 8 \\
Total & 110 & 100 \\
\hline
\end{tabular}


Table 2: Respondents opinions on Cremation of a human corpse

\begin{tabular}{lcc}
\hline \multicolumn{1}{c}{ Selection } & Total & Percentage (\%) \\
\hline Agree & 21 & 19 \\
Not Sure & 31 & 28 \\
Disagree & 58 & 53 \\
Total & 110 & 100 \\
\hline
\end{tabular}

Table 3: Coding used vis-à-vis the questions posed to the respondents

\begin{tabular}{|c|c|c|c|}
\hline Question & Answer & Coding & Rationale and Justification \\
\hline \multirow{3}{*}{$\begin{array}{l}\text { Do you agree with } \\
\text { the cremation of the } \\
\text { human corpse during } \\
\text { a disaster state? }\end{array}$} & Yes & $\begin{array}{l}\text { - Prevention } \\
\text { - Security } \\
\text { - Religion }\end{array}$ & $\begin{array}{l}\text { These coding help to understand the reason } \\
\text { respondents agree with the cremation of human } \\
\text { corpses }\end{array}$ \\
\hline & Not sure & $\begin{array}{l}\text { - Better alternative } \\
\text { - Not familiar } \\
\text { - Next of kin }\end{array}$ & $\begin{array}{l}\text { The coding from the data collected highlights the } \\
\text { uncertainty of respondents' decision whether to } \\
\text { agree or not to the cremation of human corpses }\end{array}$ \\
\hline & No & $\begin{array}{l}\text { - Inhumane } \\
\text { - Religion } \\
\text { - Respect }\end{array}$ & $\begin{array}{l}\text { The coding allows the researcher to ascertain } \\
\text { the reasons behind the disagreement of the } \\
\text { cremation of human corpses. }\end{array}$ \\
\hline
\end{tabular}

Table 4: Coding generated from QSR Nvivo software for the respondents' answers to the cremation of the human corpse during a disaster state

\begin{tabular}{lcc}
\hline \multicolumn{1}{c}{ Name } & Files & References \\
\hline Y_Prevention & 18 & 18 \\
Y_Security & 9 & 9 \\
Y_ Religion & 6 & 6 \\
NS_ Better alternative & 16 & 16 \\
NS_ Not familiar & 12 & 12 \\
NS_ Next of kin & 8 & 8 \\
N_ Religion & 27 & 27 \\
N_ Inhumane & 19 & 19 \\
N_Culture & 10 & 10 \\
\hline
\end{tabular}

\section{Discussion}

Based on the-findings, keywords have been identified by using Nvivo as shown in Table 3 and Table 4. For those respondents who agree with the cremation of human corpses during the disaster, their keywords are prevention, security, and religion. For respondents who are not sure about the cremation of human corpses during the disaster, their keywords are better alternatives, not familiar, and next of kin. For the last group of respondents who are against cremation, their keywords are inhumane, religion, and respect.
From the total number of 110 respondents, $19 \%$ of respondents agree with the cremation of human corpses in a disaster. For them, cremation of human corpses during a disaster is very crucial to prevent the spread of diseases especially COVID-19. They believe that national security is more important than anything else. Since cremation is a practice for some religions in Malaysia, some respondents believe that cremation is consistent with the teaching of their religion. For example, Hindu encourage the cremation of human corpses and Buddhism also accepts this practice. 
Meanwhile, 31 respondents are uncertain about the cremation of human corpses during the disaster. For them, there must be a better alternative than cremation. Some respondents, especially Muslims prefer to refer the matter to the higher authority, especially those who are experts in religious matters as they admitted that they are not familiar with the rules and regulations in Islam when dealing with a dead body. Another factor that concerns this group of respondents is the state of mind of the next of kin when their loved one has been cremated. To not see their loved one for the last time especially like the COVID-19 situation now, with the high possibility of the spread of COVID-19 from the dead body, the next of kin may experience emotional or mental breakdown when they can only receive the ashes of their loved one. It is important to note that Islam strictly practices the burial of the body. Therefore, even if it is a state of disaster, they still prefer to bury the deceased according to their religion.

The majority of the respondents (58 respondents) strongly disagree with the implementation of cremation during a disaster as they think that cremation is inhumane. To burn another human being is cruel and unacceptable and the dead body should be respected as it is. While it is against their religion, it is also not a common practice to cremate human corpses. Again, religion is the major issue when it comes to acceptance of cremation in a disaster. As stated by Hackett et al. (2015), 84\% of the world population acknowledge professing a religion. Therefore, when it comes to the cremation of human corpses, religion is and will always be the major concern for the acceptance of cremation even in disaster times. This finding has shown that Malaysians are not ready to accept cremation even in a state of disaster. Therefore, legislation is needed to avoid any unnecessary court case in the future against the government if the government intends to implement the cremation of the dead body during disasters.

\section{Conclusion}

From the findings, it is clear to us that cremation during disasters is still unacceptable in Malaysia. This is since the majority of the respondents believe that cremation is against their religious practices and is inhumane. They believe that there must be a better alternative rather than cremate the dead body even though the dead body is infected with a disease such as COVID-19. Interestingly, none of the respondents were concerned about sustainability issues regarding the disposal of a dead body such as the speed at which a dead body could be disposed of, impacts of the practice on the environment, and others. As such, the results signify that religion plays a major role in influencing the respondents' answers in this study, and without a law that enables the government and relevant authorities to cremate human corpses in disaster, there will be impeccable legal action taken against the government in the future. Therefore, a proper blueprint of disaster management which includes legislation regarding disposal of human corpses by cremation is crucial to maintain the national security of the country.

\section{Acknowledgements}

The authors wish to thank the university for the research opportunity and reviewers and editors for the comments on this article.

\section{References}

Bloch, M. (1992). The Historian's Craft (transl. P. Putnam), Manchester: Manchester University Press.

Childe, V.G. (1944). Progress and Archaeology, London. Watts.

Clark, G. (1960). Archaeology and Society. Reconstructing the Prehsitoric Past. London. Methuen.

Cremation. (2020). Religion and cremation. Retrieved from cremation.com/learn-aboutcremation/religion/ 
Eckerdal, R. \& Hagstrom, C. (2017). Qualitative questionnaires as a method for information studies research. Information Research, 22(1), 1-9

Everplan. (2020). Buddhist Funeral Traditions. Retrieved from everplans.com/articles/ buddhist-funeral-traditions.

Hackett, C. Stonawski, M., \& Potancokova, M. (2015). The future size of religiously affiliated and unaffiliated populations. Demographic Research, 32, 829-842.

Hutton, D (2001). Psychosocial aspects of disaster recovery: Integrating communities into disaster planning and policy making. Retrieved from https://www.iclr.org/ images/Psychosocial_aspects_of_disaster_ recovery.pdf.

Jha, M. K. (2010). Natural and anthropogenic disasters, vulnerability, preparedness and mitigation. Springer.

Kaczmarek J., Lepkowski, W., \& Zdrodowski B. (2002). Wspolczesne bezpiecezenstwo. Perspektywa teoretyczno-metodologiczna. Warszawa-Siedle.

Kitler W. (2011). Bezpieczenstwa naroowe RP. Podstawowe kategprie, uwarunkowania, system. Warszawa.

Kume, G. D. (2006). Post-traumatic stress: New research. Nova Science Publishers.

Loh, I. H., Chong, J. L., Bidin, A. \& Harun, N (2017). Malaysia disaster management of human corpse act: The fundamental role of soft law. International Journal of Applied Busines and Economic Research, 15(7), 127-138.
Loh. I. H. \& Chong, J. L. (2019). Non-cremation and mass burial principles in disaster management of human corpse. Journal of Sustainability Science and Management 14(2), 117-125.

Muhammad, A. (2001). Is cremation Prohibited in the Quran? Retrieved from quram-islam. org/articles/part_5/cremation_(P1503). html.

Piggott, S. P. (1965). Ancient Europe from the Beginning of Agriculture to Classical Antiquity. A survey. Edinburgh: Edinburgh University Press.

Rebay-Salibury, K. (2012) Inhumation and cremation: How burial practice are linked to beliefs. Retrieved from https://www. researchgate.net/publication/333063064.

The Malay Mail. (2020). MOH: Post-mortem shows coronavirus stays on skin, funeral rites can only involve body bags. Retrieved from https://www.malaymail.com/news/ malaysia/2020/04/10/moh-post-mortemshows-coronavirus-stays-on-skin-funeralrites-can-only-invo/1855513.

Uzell, J. (2018). Death and Funeral Rituals in World Religions. Retrieved from http:// religionmediacentre.org.uk/factsheets/ death-funeral-rituals-in-world-religions/.

Wikipedia. (2020). Cremation. Retrieved from https://http://en.wikipedia.org/wiki/ Cremation.

Zieba, R. \& Zajac J.(2010). Budowa zintegrowanego system bezpieczenstwa naradowego Polski. Ekspertyza. Warszawa. 